\title{
地下岩石の破壊じん性値のコアボーリングデータ を用いた簡易算定法*
}

\author{
関 根 英 樹 ${ }^{1}$ \\ 大 内 和 紀 $^{2}$
}

\section{1. 緒}

言

地款内に蓄えられている熱エネルギーは膨大な量と推定 されている。近年, 特に深部地殼に蓄えられている熱エネ ルギーの開発が注目され，日欧米の各国を中心に高温岩体 （HDR）の研究が活発に行なわれている。この次世代の 地熱開発として位置づけられる深部地殼熱エネルギーの開 発のためには, 伝熱面として利用する地下人工き裂を工学 的に設計するための基礎研究が不可欠である ${ }^{1)}$ 。一方, 浅 所の熱水・熱蒸気を利用する，いわゆる在来型地熱発電所 の地熱貯留層も天然き裂や細孔から形成されていることが 明らかとなつており, 抽出熱エネルギー増大のための地下 刺激技術開発の観点からも地下き裂の検討はきわめて重要 となつている。

地下人工き裂設計法を確立するためには, 従来岩石力学 の分野で行なわれてきた岩石の圧縮応力下での変形ならび に破壊挙動のみならず，引張応力下でのそれらの研究が必 要とされ, とりわけ破壊力学的観点からの研究が重要とな る。破壞力学に立脚すると，地下人工き裂を設計するため の第一歩注，地下岩石の破壊じん性值を把握することであ る。現在，地下岩石の破壊じん性値を知るためには，採取 されたコアについて破壊じん性試験を行なう I S R M

(International Society for Rock Mechanics) $ב$ ア試験法 ${ }^{23}$ 多ある。しかし，大量のコアについて破壞じん 性試験を行なうことは莫大な労力と時間を費やすことにな り, 地下に抢洺数の位置での破壊じん性值の把握には 適していない。本研究においては, 岩石の掘さくに対して 破壊力学的な掘さくモデルを作成し, コアボーリングデー タを用いて地下岩石の破壊じん性値を簡便に算定する方法 を考案した。

\section{2. 岩石の掘さくモデルと破壊じん性値 の簡易算定理論}

コアボーリングビットとして用いられるダイヤモンドビ ットにはサーフェイスビットとインプレグネートビットが

* 1986 年 3 月 19 日受理

1. 正会員 工博 東北大学教授 工学部基礎工学教室

2. 東北大学大学院 (現 日立製作所株)

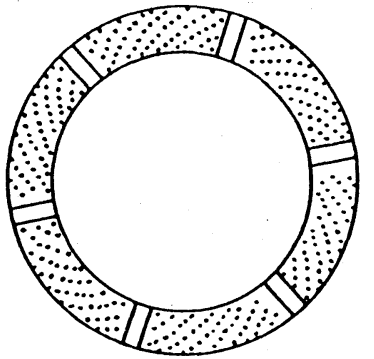

\section{第1図}

サーフェイスビットのフェイ スストーンの植込状態

ある。サーフェイスビットのフェイスストーンの植込みの 状態を示したのが第 1 図である。第 1 図からわかるように， フェイスストーンは規則的に線状をなして植込まれている。 ここでは，内周から外周にわたつて線状に植込まれたフェ イスストーンの列を岩石を掘さくするための 1 枚の刃とし て考える。ビットフェイスの幅を $B$, 線状に植込まれたフ エイスストーンの列数を $\varepsilon$, ビットにかかる全荷重, すな わち給圧を $Q$ とすると，フェイスストーンの 1 列のビット フェイス単位幅あたりの荷重 $q$ は次式で与えられる。

$$
q=\frac{h Q}{\varepsilon B}
$$

ここに，hは給圧Qのうち実際にフェイスストーンにかか る荷重の割合を示す量であり，有効給圧係数と名付ける。

岩石内部には数 $\mu \mathrm{m}$ のオーダーの多数の微小な空陌が存在 し，その空隙から微小き裂が発生することが観察されてい る $^{4) 5)}$ ○したがつて, 岩石の掘さく面には多数の微小き裂 が存在すると考えられる。岩石を均質等方弾性体と考え; アボーリング時の掘さく面上の微小き裂を半無限弾性体表 面上における表面に垂直な縁き裂としてモデル化しよう。 二次元的に考えたフェイスストーンの列のモデル化した刃 と縁き裂を第 2 図に，集中荷重 $q$ が作用する刃の移動にと もなう岩石の掘さく過程の模式図を第 3 図に示す昼）。すな わち，第 3 図(a)のように集中荷重 $q$ が掘さく面上を縁き裂 に向つて近づくと，縁き裂は先端から屈折して前方に進展 する ( 第 3 図(b) )。荷重が縁き裂を通過して第 3 図(c)の 位置にくると, 今度は逆に後方に向つてき裂は進展し, 以

a）掘さく時には, 荷重の進行方向に抵抗力 (主分力 ) が働く。この抵 抗力を掘さく時のデータから推定し, 集中荷重の摩擦力として評価 すると, 摩摖係数は $0.2 \sim 0.3$ 程度と思われる。この程度の摩擦係 数の場合には, 二次元緑き裂の屃部に集中荷重 $q$ のほかに荷重の進 行方向の抵抗力が働いても, 周応力の特異性の強さ $\bar{K}$ ( 式(3)参照) に及ぼす影響は小さくなり，結局抵抗力を無視して集中荷重 $q$ のみ が働くとしても十分である。 


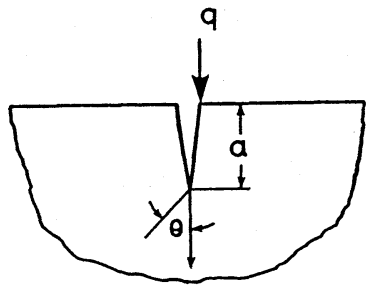

第2図 半無限体表面にお ける二次元縁き裂

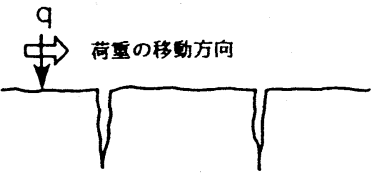

(a)

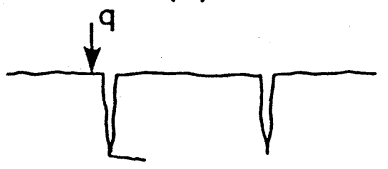

(b)

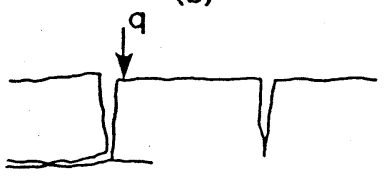

(c)

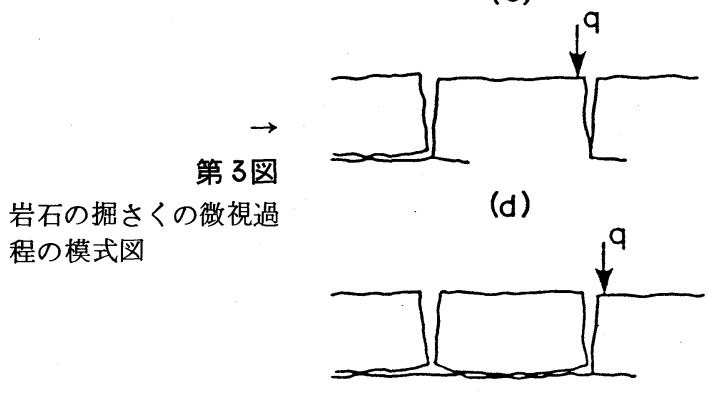

(e)

前に進展したき裂と合体して，その部分の岩石が剝落する。 その後, さらに荷重が移動すると, 同様のき裂進展と剝落 をくり返し (第 3 図(d)，(e) ), 岩石は掘さくされる。

荷重が縁き裂を通過直後, 縁き裂の先端から後方に向う き裂進展を検討するためには, き裂端での応力桩大係数を 求めなければならない。第 2 図のように，長さ $a$ の二次元 縁き裂の肩部に集中荷重 $q$ が存在する場合，き裂端でのモ ードI およびモードII の応力桩大係数 $K_{\mathrm{I}}, K_{\mathrm{II}}$ は次式で与 えられる6)。

$$
K_{\mathrm{I}}=0, K_{\mathrm{II}}=1.30 \frac{q}{\sqrt{\pi a}}
$$

き裂進展は, き裂先端近傍の周応力の特異性の強さの最 大值が破壊じん性値を越えたときに，き裂先端から最大值 を取る方向に生じるという Erdogan-Sihのき裂進展に関 するクライテリオン に) に基づくと, 周応力の特異性の強さ

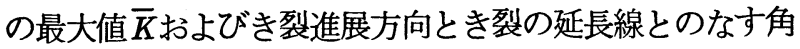
$\theta$ (第 2 図) は次式で与えられる。

$$
\left.\begin{array}{l}
\bar{K}=\cos \frac{\theta}{2}\left(K_{\mathrm{I}} \cos ^{2} \frac{\theta}{2}-\frac{3}{2} K_{\mathrm{II}} \sin \theta\right) \\
\theta=2 \tan ^{-1}\left\{-\frac{K_{\mathrm{I}} / K_{\mathrm{II}}}{} \cdot \frac{\left.\pi K_{\mathrm{I}} / K_{\mathrm{II}}\right)^{2}+8}{4}\right\}
\end{array}\right\}
$$

(2)式を(3)式に代入することにより次式が得られる。

$$
\bar{K}=0.847 \frac{q}{\sqrt{a}}, \theta=70.5^{\circ}
$$

(4)式より求まる $\bar{K}$ が岩石の破壊じん性值 $K_{\mathrm{IC}}$ を越えると 縁き裂は進展する。すなわち,

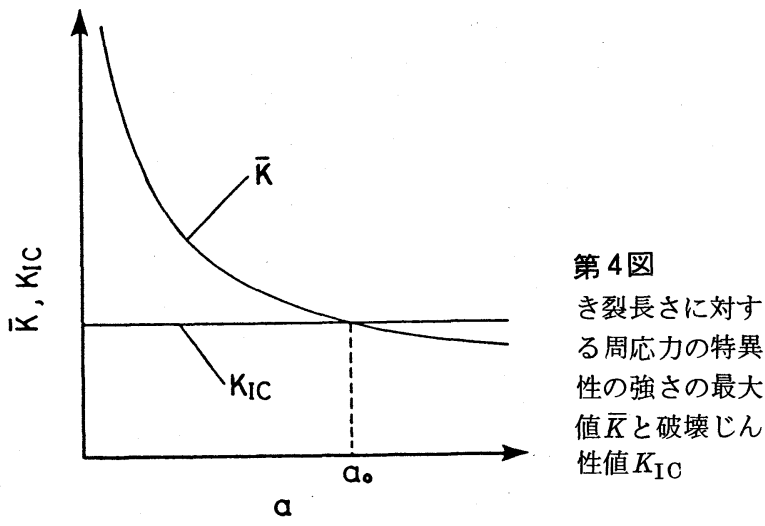

$K^{*} \equiv \bar{K}-K_{\mathrm{IC}} \geq 0$

第 4 図にき裂長さ $a$ に対する $\bar{K}$ と破壊じん性値 $K_{\mathrm{IC}}$ の関係 を模式的に示した。第 4 図からわかるようにき裂長さ $a$ が 小さくなるにしたがい， $K^{*}$ は大きくなる。岩石の剝落

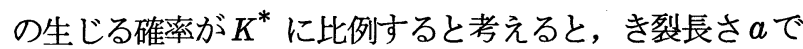
剝落が生じるときの確率密度関数は $K^{*} / \int_{0}^{a_{0}} K^{*} d a$ となり, 剝落の生じるき裂長さの平均値 $a_{m}$ は,

$$
a_{m}=\int_{0}^{a_{0}} a K^{*} d a / \int_{0}^{a_{0}} K^{*} d a
$$

ここに， $a_{0}$ は(5) 式の等号が成立するときのき裂長さであ

り, 次式によつて与えられる。

$$
a_{0}=0.717-\frac{q^{2}}{K_{\mathrm{IC}}^{2}}
$$

(1)，(4)，(5)式抢よび(7)式を用いて(6)式を計算すれば

$$
a_{m}=0.120 \frac{h^{2} Q^{2}}{\varepsilon^{2} B^{2} K_{I C}^{2}}
$$

したがつて, 単位時間あたりの掘進長, すなわち掘進率 $L$ は

$$
L=\varepsilon N a_{m}=0.120 \frac{N h^{2} Q^{2}}{\varepsilon B^{2} K_{\mathrm{IC}}^{2}}
$$

ここに，Nは単位時間あたりのビットの回転数である。ビ ットの回転数が一定のとき硬い地層では, 掘進率 $L$ は給圧 Qの 2 乗に比例することが実験的に明らかにされている゙。 (9)式はこの事実をよく説明している。(9)式から破壊じん性 值 $K_{I \mathrm{IC}}$ は次式のように得られる。

$$
K_{\text {IC }}=0.346 \sqrt{\frac{N}{\varepsilon L}} \frac{h Q}{B}
$$

さて, 破壊じん性值の算定の手順を述べよう。有効給圧

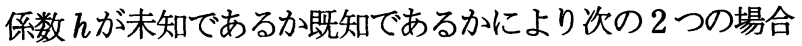
に分かれる。

\section{（i）有効給圧係数が末知の場合}

この場合には，まずュアを用いて破壊じん性試験を行な い, 破壊じん性值 $K_{\mathrm{IC}}$ を得る。求めた $K_{\mathrm{IC}}$ と $B, \varepsilon$ の值お よびュア採取位置のビット回転数 $N$, 給圧 $Q$, 掘進率 $L$ を

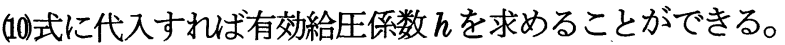
その值 $h$ と地下の各位置のビット回転数 $N$, 給圧 $Q$, 掘進 率Lを用いれば，(10)式から地下岩石の破壊じん性値 $K_{\mathrm{IC}}$ が 
地下岩石の破壊じん性値のコアボーリングデータを用いた簡易算定法 $\square$

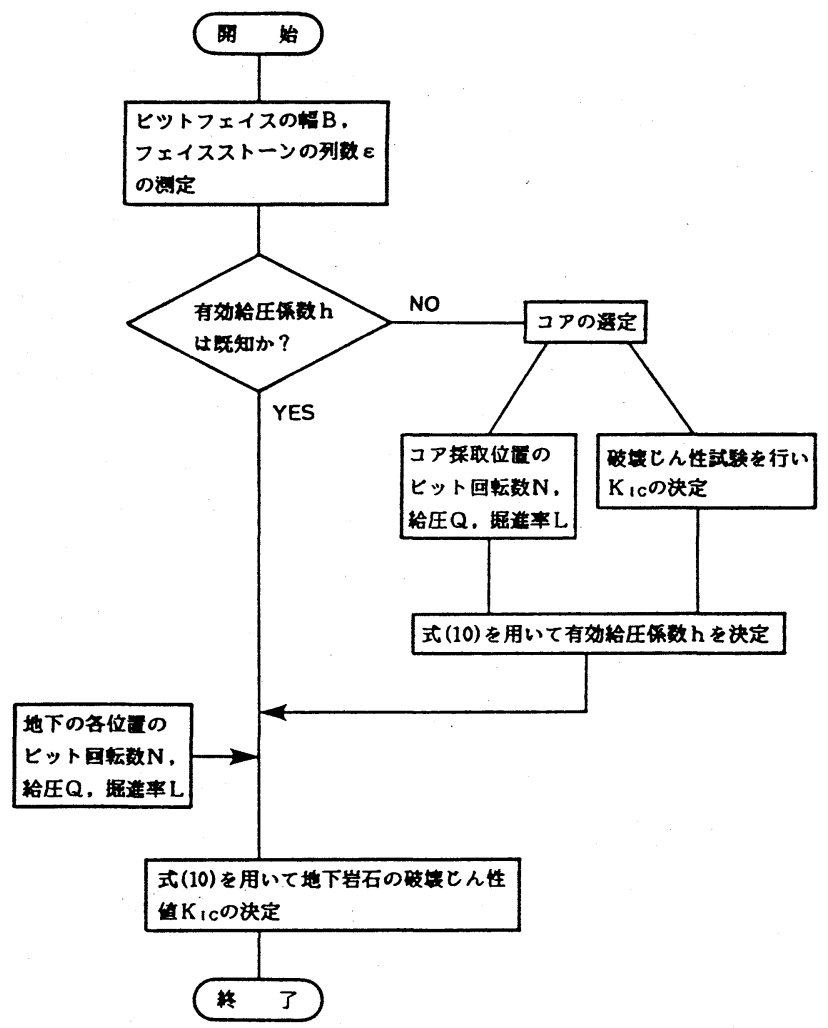

第5図 地下岩石の破壊じん性值決定の流れ図

決定できる。

\section{(ii) 有効給圧係数力溉知の場合}

このときは, $B, \varepsilon$ の値および地下の各位置のビット回 転数 $N$, 給圧 $Q$, 掘進率 $L$ を用いて, 直接(10)式から地下岩 石の破壊じん性值 $K_{\mathrm{IC}}$ が決定できる。

上述の (i ), (ii) の場合の破壊じん性值の算定法の流れ 図を第 5 図に示す。

\section{3. 具体的適用例}

東北大学東八幡平実験フィールドでの坑井の掘さくにより 得られた地下の 3 位置のコアについて， I S R M コア試験 法を用いて求めた破壊じん性值と本算定法により求めた破 壊じん性值との比較を試みる。コアボーリングにはワイヤ ーラインコアビット HQ 101が用いられた。ビットの外径は $101 \mathrm{~mm}$, 内径は68mmであり, ダイヤモンド鋳込量は 45 C Tである。コアの岩種およびュアボーリング時の掘さく 条件, 掘進率を第 1 表に示す。

各コアについて，I S RM アア試験法を用いて求めた破 壞じん性值 $K_{\mathrm{IC}}$ を第 2 表に示す。これらの值および第 1 表 に示したビット回転数 $N$, 給圧 $Q$, 掘進率 $L$ を(10)式に代入 し，各コアに対する有効給圧係数 $h$ を計算した。なお， $B$ は $16.5 \mathrm{~mm}, \varepsilon$ \& 54 である。その結果, I , II , IIIの各ュア の有効給圧係数はそれぞれ，0.38，0.29，0.35 であり平 均値として 0.34 を得た。第 1 表の各值と有効給圧俰数の 平均値を(10)式に代入すると, 本方法による地下の 3 位置の
第1表 コアの岩種およびュアボーリング時の掘 さく条件, 掘進率

\begin{tabular}{|c|c|c|c|c|c|}
\hline$\beth \boldsymbol{J}$ & $\begin{array}{c}\text { 深 度 } \\
(\mathrm{m})\end{array}$ & 岩 & $\begin{array}{l}\text { ビット } \\
\text { 回転数 } N \\
(\mathrm{rpm})\end{array}$ & $\begin{array}{c}\text { 給 圧 } Q \\
(\mathrm{kN})\end{array}$ & $\begin{array}{l}\text { 掘進率 } L \\
(\mathrm{~m} / \mathrm{min})\end{array}$ \\
\hline I & 352 & $\begin{array}{l}\text { ディサイト質 } \\
\text { 凝灰岩 }\end{array}$ & 220 & 8.82 & 0.055 \\
\hline II & 408 & $\begin{array}{l}\text { ディサイト質 } \\
\text { 凝灰岩 }\end{array}$ & 280 & 13.72 & 0.060 \\
\hline III & 449 & 凝灰質砂岩 & 315 & 13.23 & 0.052 \\
\hline
\end{tabular}

第 2表 破壊じん性值の I S R M コア試験法による 実験値と本方法による算定値

\begin{tabular}{c|c|c}
\hline コ & 実験值 $\left(\mathrm{MP} \mathrm{am}^{1 / 2}\right)$ & $\begin{array}{c}\text { 本方法による算定値 } \\
\left(\mathrm{MP} \mathrm{am}^{1 / 2}\right)\end{array}$ \\
\hline I & 0.60 & 0.54 \\
II & 0.77 & 0.91 \\
III & 1.03 & 0.99 \\
\hline
\end{tabular}

破壊じん性值の算定値が第 2 表のように得られた。本方 法による算定値は I S R M コア試験法による実験値と相当 よく一致しており, 地下岩石の破壊じん性値の算定に本方 法はきわめて有効であることが理解できる。

\section{4. 結言}

コアボーリングビットによる岩石の掘さくに対して, 破 壊力学的な掘さくモデルを作成し, コアボーリングデータ から地下岩石の破壊じん性值を簡便に求める算定式を導い た。東北大学東八幡平実験フィールドで得られたュアにつ いて，I S R M コア試験法を用いて求めた破壊じん性值と 本方法より求めた破壊じん性值を比較した結果, 相当よく 一致しており，地下岩石の破壊じん性値の算定に本方法は きわめて有効であるという知見を得た。

謝辞 本研究の遂行にあたり東北大学工学部阿部博之教 授ならびに東北大学工学部地熱開発工学研究グループ ( G E E E ）の各位より有益なご討論をいただいた。ここに記 してお礼申し上げる。なお, 本研究は昭和 59 年度文部省科 学研究費特別推進研究(2)課題番号 58065002 によるもの であることを付記し謝意を表する。

\section{参考文 献}

1) Nemat-Nasser, S., Abé, H.\& Hirakawa, S. (Eds.) : Hydraulic Fracturing and Geothermal Energy, (1983), Martinus $\mathrm{Nij}$ ihoff Pub. (Hague)

2) Ouchterlony, F.: SveDeFo Report DS 1982: 5, (1982)

3) Ouchterlony, F. : Sve DeFo Report DS 1983: 10, (1983)

4) Sprunt, Eve, S.\& Brace, W. F. : Int. J. Rock Mech. $\mathrm{M}_{\text {in. }}$ S ci. \& Geomech. Abstr., 11, 139 150, (1974)

5) Lindqvist, P. -A., Lai, H. H. \& Alm, O. : Int. J. Rock Mech. Min. Sci.\& Geomech. Abstr., 21, 165 182, (1984)

6) Tada, H., Paris, P., \& Irwin, G: The Siress Analysis of Cracks Handbook, 8. 2, (1973), Del. Res. Corp. (Hellerton)

7) Erdogan, F.\& Sih, G.C.: Trans.ASME, J. Basic Engng., 85, 519 527, (1963)

8）岩松一雄：ボーリングハンドブック，21～22, (1973), 森北出版 (東京) 


\section{A New Method for the Determination of Fracture Toughness of} Rock by the Use of Core Boring Data

by Hideki SEKINE ${ }^{1}$ and Katsunori OUCHI ${ }^{2}$

This paper describes a new method for the determination of fracture toughness of rock by the use of core boring data. In order to examine the validity of this method, the fracture toughness values of the core specimens at the Eastern Hachimantai field, the model field of the $\Gamma$-project at Tohoku University, were compared with those evaluated by this method. Then, both results agreed satisfactorily. This method could be also useful to in situ measure the fracture toughness value of rock.

1. Prof., Dr., Faculty of Engineering, Tohoku Univ.

2. Graduate Student, Graduate School of Engineering, Tohoku Univ.

\section{写真鉱業史 9 \\ 芹ケ理会川金川长路 \\ 葉賀七三男 日本鉱業会調查役}

最近45年ぶりに鹿児島を訪れた。芹ヶ野 谷山両鉱山跡を調査するのが目的であつた が，現地では三井串木野鉱山山本日出雄社 長はじめ鉱業所の皆々様の御尽力で望外な 資料・史料にお目にかかることができた。特 に 50 年前鉱業所に勤めた経験のある地元郷 土史家の竹中武夫氏の御案内で，1 日芹ケ 野金山跡一帯を櫭なく調査することができ た。篤く各位に深謝申し上げる次第である。 問題の第 1 は, 「地調查所報告」No. 9 （明治41年12月刊）には芹ヶ野金山には自 稼人が水車 213 台を使つて搗鉱混手製錬を していたと記載されている。そんなに沢山

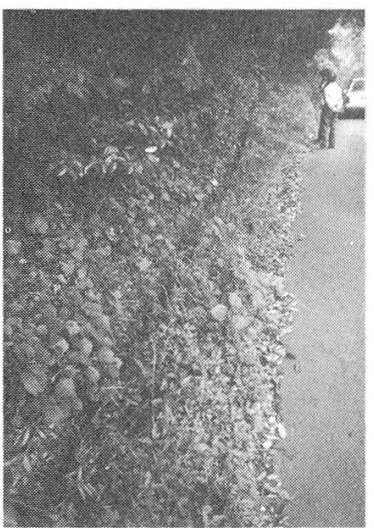

太郎坊水路跡
の水車が一地区に設置できたであろうかと いう点であつた。

現地調査と竹中氏の教示で, 旧芹ヶ野地 区は山が浅く，水量が枯れるおそれがある ので，金鉱石は現串木野鉱山のある西山を 越え, さらに西方にある太郎坊一帯の, 山 は低いが，奥行が深く，年中水量の枯れな い所まで運搬して搗鉱製鍊していたことが 判明。現地でも往時の水路が残つていると いうので, 串木野鉱業所の車でわざわざそ の遺構まで案内していただいた。

写真に示すごとく, 水路の幅は約 30 セン チ, 梁さもほぼ同様であつたが，谷は奥が 深く相当上流まで田圃が開かれているので, 年中水が枯れることがなかつたものと推量 された。しかも, 水車は両側に捣鉱機を設 備し, その中央で水車が回転駆動力を与え

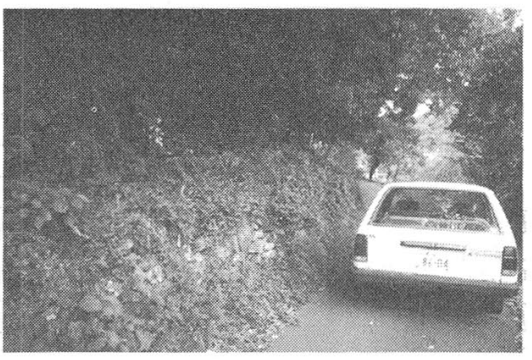

太郎坊水路 (左石垣上)
る方式で, 間隔を明けずに水路にビッシリ 建設することが可能であつた。したがつて， この太郎坊付近では前記のと扔り 200 に及 ぶ多数の水車が稼行できたものと，はじめ て納得できた。

案内をしていただいた竹中氏の身内の方 で，芹ケ野から鉱石を付けた牛を追い，山 越えで太郎坊に運び続けた方がおり，その 詳細をうかがつている旨を親しく教えてい ただいたが，昔の金山では粉成は大切な工 程であり, それは谷川の水量に大きく左右 されていた事実を現地に確認できたのは大 収穫であつた。薩摩金山独特の稼行方式自 稼法も, これら水車の存在が大切な要件で あつた点も，よく理解することができた。

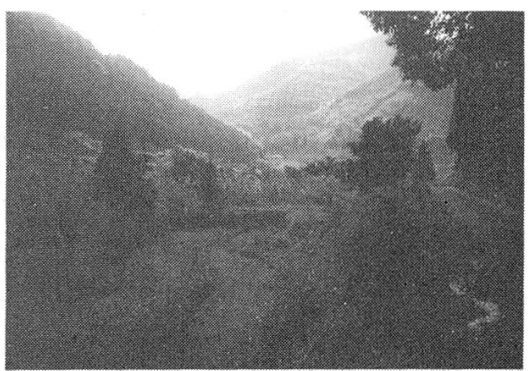

太郎坊の景観

（右側道路脇に水路あり）

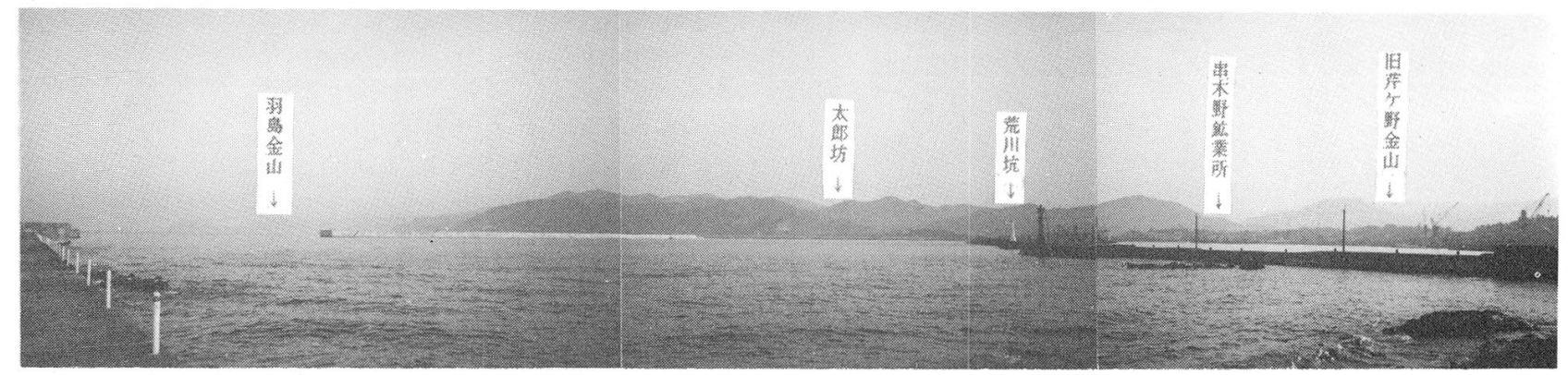

串木野市長崎の鼻公園から西北方を望む。右手は串木野港

( 左から羽島金山，太郎坊 (前面の低い所), 荒川坑，串木野鉱業所，旧芹々野鉱山） 